\title{
Gram-ghost cells
}

Yoshiro Hadano

Department of General Internal Medicine and Infectious Diseases, Rakuwakai Otowa Hospital, Kyoto, Japan

\section{Correspondence to} Dr Yoshiro Hadano, hatayoshiyoshi@gmail.com

\section{DESCRIPTION}

To cite: Hadano Y. BMJ Case Reports Published online: [please include Day Month Year] doi:10.1136/ bcr-2012-008477
A 65-year-old Japanese man with advanced lung cancer was admitted with a 2 -week history of cough and general fatigue. On physical examination, the patient appeared to be chronically ill; his blood pressure was $115 / 52 \mathrm{~mm} \mathrm{Hg}$, pulse rate was 97 beats/min and regular, temperature was $37.3^{\circ} \mathrm{C}$, respiratory rate was $24 / \mathrm{min}$ and peripheral arterial oxygen saturation was $93 \%$ on room air. Chest examination revealed decreased right breath sounds in the right chest region, and a plain chest $\mathrm{x}$-ray revealed massive right pleural effusion. Thoracentesis was performed on the day of admission and Gram's staining of the pleural fluid revealed birefringent and colourless bacilli ('Gram-neutral' or 'gram-ghost') admixed with polynuclear leucocytes (figure 1). In the examination conducted using a longer focal distance, weakly stained, gram-positive rods were detected (figure 2). An additional study confirmed by Ziehl-Neelsen staining demonstrated acid-fast rods admixed with polynuclear leucocytes, which were strongly suspected to be mycobacteria (figure 3).

Mycobacterium tuberculosis: PCR was positive and pleural fluid culture grew $M$ tuberculosis.

Gram-ghost appearance refers to the gram-neutral (neither positive nor negative) appearance of mycobacteria on Gram's staining. ${ }^{1}$ In general, most internists and infectious disease specialists in Japan perform Gram's staining, especially in the setting of emergency room. Recognition of gram-ghost bacilli on the initial Gram's staining is useful, because it provides an early diagnostic clue, before the presence of mycobacteria can be confirmed by Ziehl-Neelsen's staining.

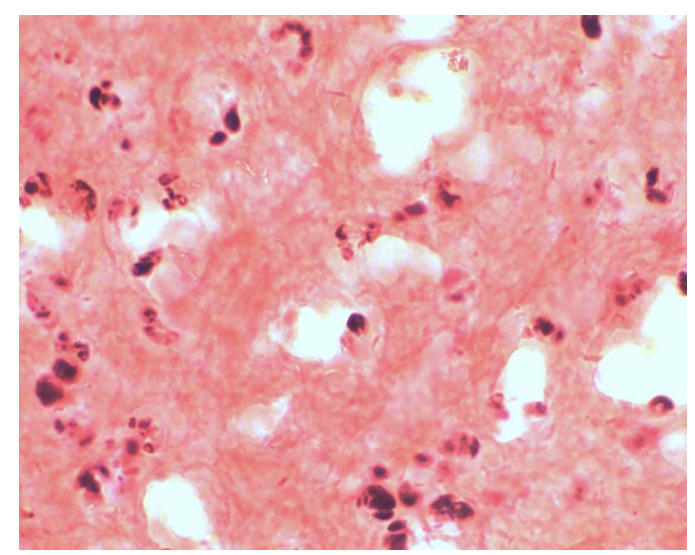

Figure 1 Gram's staining of the sputum under appropriate focus $(\times 1000)$.

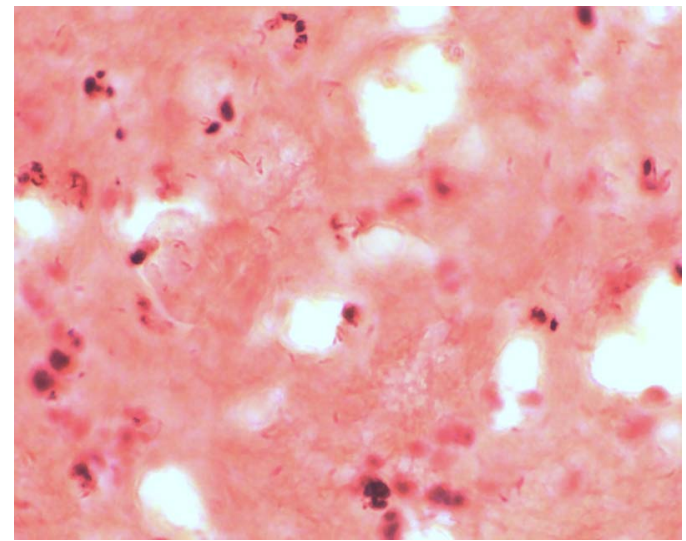

Figure 2 Gram's staining of the sputum under a mildly longer focal distance $(\times 1000)$.

\section{Learning points}

In the presence of gram-ghost cells by gram's staining is strongly suspected to be mycobacteria. Gram's staining is useful as an easy and rapid diagnostic clue to recognize infective mycobacteria.

\section{REFERENCE}

1 Trifiro S, Bourgault AM, Lebel F, et al. Ghost mycobacteria on gram stain. J Clin Microbiol 1990;28:146-7.

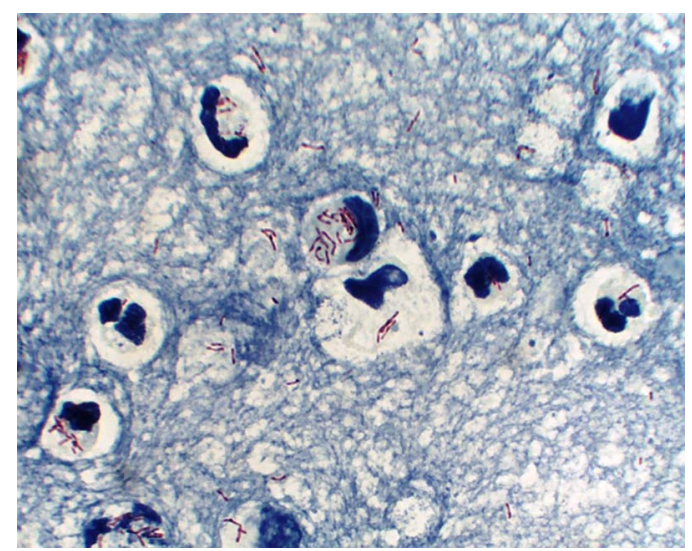

Figure 3 Ziehl-Neelsen's staining under appropriate focus $(\times 1000)$. 
Copyright 2013 BMJ Publishing Group. All rights reserved. For permission to reuse any of this content visit http://group.bmj.com/group/rights-licensing/permissions.

BMJ Case Report Fellows may re-use this article for personal use and teaching without any further permission.

Become a Fellow of BMJ Case Reports today and you can:

- Submit as many cases as you like

- Enjoy fast sympathetic peer review and rapid publication of accepted articles

- Access all the published articles

- Re-use any of the published material for personal use and teaching without further permission

For information on Institutional Fellowships contact consortiasales@bmjgroup.com

Visit casereports.bmj.com for more articles like this and to become a Fellow 